\title{
Acquisition of ASPECT and AKTIONSART by children in Croatian and French
}

\author{
Claire Martinot, Université René Descartes (Paris 5) \\ cmartinot@aol.com \\ Maja Andel, Zagreb University \\ tazenda31@yahoo.com \\ Sunil Kumar, Zagreb University \\ tazenda31@yahoo.com
}

\begin{abstract}
Our results indicate some differences in the use of aspect between French and Croatian speaking children. In Croatian language children always manage to keep the appropriate aspect, unlike French children. However, the imperfective aspect seems to be better acquired in French children than the perfective aspect. The perfective aspect, the marked form both in French as well as in Croatian, is related to the lexical meaning of the verbs. The acquisition of the Aktionsart in both languages seems to be more a matter of semantics than of morphology. Furthermore, our data suggest the existence of a specific developmental trend in the use of Aktionsart (intensive, iterative and inchoative), which is similar for children speaking Slavic and Romanic languages.
\end{abstract}

\section{$1 \quad$ Introduction}

The aim of this study is to examine the use of verbal aspect and the Aktionsart: intensive, iterative, and inchoative, by the children between 4 and 12 years of age in a Slavic language like Croatian, and in a Romanic language like French.

\section{Subjects and Method}

We have examined children's retellings of the story «Deux amis malheureux» (Two unhappy friends), a popular tale from Northern Europe. The original text has been translated from French (Martinot, 2000) into Croatian (Andel et al, 2003) The appropriate translation of the text was administered individually to French- and Croatian-speaking children.

After the story has been read to a child twice, he/she retold the story to the examiner. Each retelling has been audio recorded, and recorded samples have been transcribed in CHAT format (Sokolov, Snow, 1994; MacWhinney 1995). The source text consists of 16 sequences forming a complete story.

\section{Participants Croatian Group}

Fourteen children participated in the study. All children, whose parents come from different regions of Croatia, live in Zagreb. Six participants were boys and eight were girls, with chronological age between 6;0 and 12;1. Only the youngest child did not attend primary school at the time. We have divided the children into 4 groups, according to their age: the first group -6 years $(3$ children), the second $-7-8$ years $(5$ children $)$, the third -9 years $(5$ children), and the fourth, consisting of only one child (12 years). 


\title{
Participants French Group
}

Eighteen French-speaking children participated in the study. All children live near Paris. Children were divided into 3 groups of 6 children each. The first one $-5-6$ years - attend the third or last class of nursery school; the second one - 7-8 years - attend the second class of primary school; and the third one $-10-11$ - the fifth or the last class of the same primary school.

\section{The verbal aspect}

\subsection{Expression of the verbal aspect in Croatian}

Verbal aspect - perfective and imperfective - as a semantic as well as morphological category is one of the typical characteristics of the Slavic languages, thus Croatian is no exception. While using the terms "perfective" and "imperfective", one must keep in mind the fact that they have nothing to do with temporal meaning of perfect and imperfect verbal tenses.

The classical definition of perfective and imperfective aspect says (Baric et al, 1997):

- The verbs, which indicate an action in process, are called the verbs of imperfective aspect.

- The verbs, which indicate an action as completed one, are called the verbs of perfective aspect.

But this definition lacks vital information about the totality of an action, i.e. action taken as a whole. The opposition of perfective and imperfective verb does not depend on the completeness or incompleteness of an action, rather on totality or entirety of an action. If the action is taken in its entirety and cannot be divided into phases, such actions are expressed by the verbs of perfective aspect.

"The main characteristic of the opposition of perfective and imperfective aspect is not the completeness or incompleteness of an action, rather divisibility and indivisibility of the action. A perfective action indivisible into the phases can never go with phase verbs such as start, finish, continue etc." (Ridjanovic, 1976)

Comrie (1976) explains the position of a speaker when he uses perfective or imperfective verb. The choice of aspect very much depends on the internal structure of the situation:

\begin{abstract}
"The perfective looks at the situation from outside, without necessarily distinguishing any of the internal structure of the situation, whereas the imperfective looks the situation from inside, such as crucially concerned with the internal structure of the situation, since it can both look backwards toward the start of the situation, and look forwards to the end of the situation."
\end{abstract}

In the opposition of perfective and imperfective verbal aspect only the perfective aspect is the marked category, the imperfective is the unmarked one. Thus, the perfective verbs express perfective actions. However, it is not the case with imperfective verbs: While they are unmarked for perfectivity in the aspectual sense, they are capable of expressing imperfective as well as perfective action. Perfectivisation in Croatian language is accomplished through prefixation and suffixation. The imperfectivisation is marked through suffixation only. The real pairs, in which verbs differ only in their aspects, are formed through suffixation only. When perfective verb is formed with prefix, it is not the real aspectual counterpart in the pair, because the prefix, along with perfectivity carries an additional information about the action, i.e. how the action is performed. The process of perfectivisation through prefixation with an additional meaning to the new formed verb is called "Aktionsart". Croatian, along with other south Slavic languages like Serbian, Bulgarian, Macedonian, etc., has special position among 
Slavic languages. In Croatian and abovementioned south Slavic languages, the verbal aspect has a temporal value, the aspectual contrast is preserved in tense formation as well. The aorist is formed only with perfective verbs and the imperfect only with imperfective verbs. This information will be of some value in the analysis of children's productions, since the original story contained some verbs in the mentioned tenses.

For the purposes of our research, we have divided the verbs from the source story and those produced by our subjects into 4 categories:

1) perfective verbs

2) imperfective verbs

3) verbs denoting both aspects

4) verbs outside aspectual category (auxiliaries, modal verbs - the aspect of the sentence is determined by the main verb; these verbs have been excluded from our analysis).

The boundaries between categories, especially 2 and 3, can sometimes be extremely hard to establish. In a given context, verbs denoting both aspects can be assigned with an aspectual value.

Some perfective and imperfective verbs can only have one aspectual form that is closely linked to their semantic content. This means, for example, that the verb ž ivjeti (to live), used in the sequence no. 1, can only exist in the imperfective form, if we exclude some semantically distant variants obtained by prefixation, like prež ivjeti (to survive). On the other hand, as explained in the introduction to Croatian verbal aspect, switching between the imperfective and perfective form of a verb can occur in two different ways. However, only through suffixation we can obtain a real aspectual opposition (ex.: puštati-IMPF - pustiti-PF, to let out - sequence no. 3). The perfectivisation by means of prefixation inevitably alters the Aktionsart of the verb. Needless to say, we must always bear in mind that the situational context is the principal element to determine what verbal aspect one should use to describe a particular semantic content.

\subsection{Expression of the verbal aspect in French}

In French language, the existing opposition between perfective and imperfective aspect is expressed differently compared to Slavic languages. French language doesn't use either prefixation or suffixation in the verbal system to express perfective $v s$ imperfective aspect. Usually, one considers that the aspectual opposition imperfective/perfective is carried out through verbal simplex vs. compound form (4 simplex tenses and 4 compound tenses respectively). But in actuality, the formal expression of opposition (simplex/compound verbal form) has to be looked through the semantic opposition between completeness (compound forms) and incompleteness (simplex forms) of an action :

$\begin{array}{lll}\text { je mange } & \text { jo. } & \text { j'ai mangé } \\ \text { (I am eating) } & & \text { (I have eaten) }\end{array}$

je mangerai mieux demain $\quad v s$. j'aurai mangé quand nous partirons

(I will eat better to morrow) (I'll have eaten when we 'll leave)

je mangeais quand l'orage a éclaté vs. j'avais mangé quand l'orage a éclaté

(I was eating when the storm broke) (I had eaten when the storm broke) 
This opposition doesn't work anymore with the simple tense passé simple (Past Historic) and the compound tense passé antérieur (Past Anterior). This latter form, like the 3 other compound forms, express a completeness value :

dès que j'eus mangé je partis immédiatement

(as soon as I had eaten I left immediately)

The passé simple doesn't express an incompleteness value like the 3 others simplex forms but a perfective value (Comrie, 1976) :

je mangeai, je bus et je partis

(I ate, I drank and I left)

With the 4 compound forms, one can add the phase verb: finir de (finish to) without any semantic change :

J'ai mangé = j'ai fini de manger

(I have eaten $=\mathrm{I}$ have finished eating)

The simplex forms in present, future and imperfect express incompleteness but not the simplex form in passé simple.

If we describe the verbal tense system in French language with the same criterion as in Croatian language, we can obtain the following classification of verbal forms :

Imperfective aspect (Baric et al, 1997, Comrie, 1976, Ridjanovic, 1976) is expressed by the present, future and imperfect tenses (3 simplex forms) and perfective aspect only by the passé simple ( 1 simplex form). The 4 compound forms divide the referred process into phases.

\section{The Aktionsart}

\subsection{Expression of the Aktionsart in Croatian}

Switching between aspects by the means of prefixes in Croatian often means changing the verb's Aktionsart. Every prefix carries certain meaning and changes the original verbal semantic. In their stories, children skilfully use variants of given prefixed verbs, with or without change in the Aktionsart, but always keep the appropriate aspect:

"Pomozi mi izbusiti rupu u ledu." (VIK, 6;02) (source: probiti, synonyme of pro-busiti)

"Help me make a hole in the ice." - source and variant completive

"Baka je izasla van iz kucice." (HEL, 7;11) (source: sisla)

"[The old lady] came out of the house." - source and variant egressive

If we move from the morphological (verb) to the syntactic level (predicate), there are even more possibilities of modifying the verb's Aktionsart, namely, the use of different adverbs to verbs, adjectives to objects or predicatives (different parts of the predicate), combinations of verbs (phase verbs) etc. Although, this change of perspective leads us more towards a semantic analysis, as opposed to a purely grammatical one, focused on the Aktionsart in the prefix or the suffix of the verb itself, a prominent (but idiosyncratic) feature of Slavic verbs. Furthermore, it has to be noted that not every verb can be assigned into a category of Aktionsart with certainty, because the boundaries between them can sometimes be a little unclear. 
Aktionsart - intensive, durative, inchoative, continuative, completive, resultative... (and many more):

The Aktionsart in Croatian can be examined on two levels - the morphological (verbal, within the verb itself) and syntactic (within the whole predicate).

1. Verb itself - by means of prefixes

Jana je govorila engleski.

(Jana spoke English. - aspect: imperfective, Aktionsart: durative)

Jana je progovorila engleski.

(Jana started to speak English. - aspect: perfective, Aktionsart: inchoative)

2. Phase verbs - to express which part of the action is described

Jana je pocela govoriti engleski.

(Jana started to speak English.)

3. Adverbs - to intensify the meaning of the predicate (very, hardly...), to express the iterativity (often, sometimes...)

4. Adjectives as (or to) predicatives - especially if in comparative or superlative, to intensify the predicate

5. Multiple negation - possible in Croatian, used as intensifier

Nije nikoga ni cula. - triple negation

(She did not even hear anyone.)

6. Verb iteration - intensifies the meaning of the verb, or indicates iterativity

\subsection{Expression of the Aktionsart in French}

In an analytic language, such as French, the information about the Aktionsart have to be searched in the whole sentence. They do not necessarily have a morphological basis, as it is the case in the Slavic languages (G.Gross, 1996: 61). In French, the Aktionsart can be expressed by different lexical word categories or sometimes by different morphological means (affixes).

1. Predicative verbs express one or more aspectual meanings because of their lexical meaning:

a. Pierre a regardé la télévision (durative)

(Peter has watched TV)

b. Hier Pierre a téléphoné à tous ses amis (iterative)

(Yesterday Peter has phoned all his friends)

The iterative Aktionsart of (b) is not only expressed by the meaning of a téléphoné (has phoned) but also by the plural form of à tous ses amis (all his friends) (in this case there are several calls) $v s$ b': 
b'. Hier Pierre a téléphoné à Marie pendant 3 heures (durative: only one call) (Yesterday Peter has phoned Mary for 3 hours)

2. Predicative nouns express an aspectual meaning. They are actualised by an appropriate support verb, which gives information on the internal nature of the course of the event: the Aktionsart (W.Frawley, 1992).

c. Luc fait son travail ( $\mathrm{N}$ durative): the sentence expresses a durative meaning (Luc is doing his work)

d. Luc entame son travail ( $\mathrm{N}$ durative: the sentence expresses an inchoative meaning) (Luc begins his work)

e. Luc a terminé son travail ( $\mathrm{N}$ durative: the sentence expresses a resultative meaning) (Luc has finished his work)

3. Adverbs like: souvent (often), des fois (sometimes), un coup ...un coup (once ... once)... express an iterative meaning; pour une fois (for once, unusually) expresses a punctual meaning, toujours (allways) a durative or iterative meaning ...

4. Adjectives express all possible aspectual meanings : une explosion instantanée (an instantaneous explosion - punctual meaning)

5. The prefix: re-(redemander - to ask once again, j'ai refaim - I am hungry once again); the suffixes: -ailler (criailler - to grouse), -eler (voleter - to flutter), -iller (sautiller - to skip) express an iterative meaning.

\section{$4 \quad$ Results}

\subsection{Results obtained from Croatian children}

\subsubsection{Aspect}

The first thing to be observed in children's stories is that, regardless their age, they easily follow the aspectual pattern of the story. This means, to retell the first part of the story, they mostly use imperfectives, and for the second perfectives, or imperfectives, with respect to the context and the source story. If some synonym verb is used to replace another from the source story, it is (almost) always in the appropriate aspect (ex.: "I tako je zaba morala probusiti, napraviti rupu u rijeci." (ROK, 9;02) "So the frog had to make a hole in the river." (source: probiti); "Samo joj je govorila da cisti, da mete pod i da pere sudje." (MAG, 6;10) "She just kept telling her to clean, to sweep the floor and to wash the dishes." (source: no verb - other subject: She had to...).

Six (out of 14) children from our sample did not use any adverbial sign to mark that the first part of the story is over and that they are beginning with the other. This has been observed mostly with younger children. This is possibly due to the fact that younger children still lack some narration skills. Nevertheless, the verbal aspect in Croatian makes possible to differentiate between two portions in their narrations. So the most important clue to this shift has been their sudden switching from imperfectives to perfectives: 
"Samo joj je govorila da cisti, da mete pod i da pere sude. Onda je rekla da donese vode...” (MAG, 6;10)

"She just kept tellingIMPF her to cleanIMPF, to sweepIMPF the floor and to washIMPF the dishes. Then she saidPF to her to bringPF some water...” (MAG, 6;10)

"Bakica je tjerala zabicu da cisti sude, da mete, da posprema, da ide na plazu po vode. A kad je dosla zabica na plazu po vode...” (IVA, 7;04)

"The old lady forcedIMPF the little frog to do the dishes, to sweep, to clean, to go to the beach to get some water. And when the little frog camePF to the beach to get some water...” (IVA, 7;04)

The need to put the verb in the correct aspectual form (which means, the native speaker's competence) is strong, even with very young children. If they do not find the exact verb right away, they are prepared to accomplish even some very complicated operations, such as imperfectivising an already perfectivised verb, instead of going back to the imperfective, simple one. No matter what operation children use, it does not always result in a confirmed verb, but the aspect is usually correct:

“Bakica ju je natjeravala da radi." (MIS, 6;06)

"The old lady always forced her to work."

tjerati-IMPF $>$ na-tjerati-PF > na-tjera-va-ti-IMPF

“... i onda je *dovikala-PF:” (SAB, 8;08)

“... and then she shouted:"

“Oh, povice-PF bakica...” (source)

"Oh, shouted (started to shout) the old lady..."

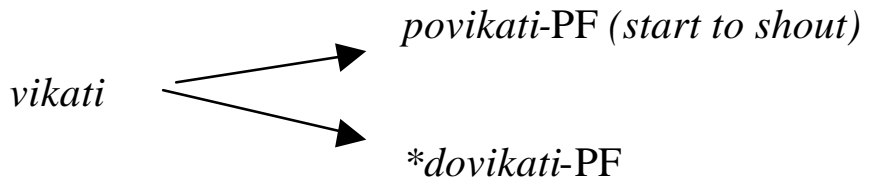

Some aspectually well-defined verbs have synonyms with two aspects. They are somewhat rare in the language, yet children have no difficulties in substituting them, this way they show a developed ability to feel the aspectuality in all its colours and functions.

“Pogledala (je) u mjesec i vidjela-2ASP psica...” (ADR, 9;0)

"She looked at the moon and saw the little dog..."

"Podigla glavu i vidjela-2ASP njih..." (MIS, 6;06)

"She raised her head and saw them..."

“Bakica ljutito podigne pogled prema mjesecu i sto ugleda-PF?” (source)

"The old lady raised angrily her head towards the moon, and (you know what she) $\underline{\text { saw? }}$ ?"

“Djevojcica je radila-2ASP sav posao za zabom.” (SAB, 8;08)

"The little girl did all the work (after the frog left)." 
“... koja je sama morala obavljati-PF sav posao zelene zabice.” (source)

"... who had to do alone all the work of the little green frog."

\subsubsection{Aktionsart (syntactic level - predicates)}

\subsubsection{Intensive Aktionsart}

- If the predicate in the source text is intensified by using an adverb:

bijase veoma sretna (was very happy)

bijase posve nesretna (was entirely unhappy)

toplo odijevala (put warm clothes on someone)

6-years-old children use mostly only one intensifying adverb per child, for all given instances (very or well), veoma sretna > jako sretna (very happy), posve nesretna > jako nesretna (very unhappy) (VIK, 6;2); veoma sretna $>$ dobro se zabavljala (she had a good time/was well entertained) (MAG, 6:10). This is sometimes a litteral repetition of the source text, but most of the time just a simplification of the source.

7-8 years old children still repeat or use (almost) exact synonymes (e.g. toplo odijevala > toplo oblacila), but are more ready to vary different syntactic constructions: bijase posve nesretna > bijase jos tuznija (was even more unhappy) - predicative $=$ adjective in comparative.

9 years old children are already able to make different variations and use different syntactic constructions, adding intensifiers where they are only implicated in the source: voljela je (she loved) > najvise je voljela (she loved the most).

The 12 years old boy varied the given constructions as well: voljela je (she loved) > najvise je voljela (she loved the most); he also summarises the meaning and the value of several verbs and indicates the time span of the action: ...bakica ju je voljela, milovala, toplo odijevala $i$ hranila mnogim ukusnim jelima (... the old lady used to feed her, put warm clothes on her and feed her with many delicious dishes) > stalno ju je njegovala (she used to take good care of her all the time).

- If the intensity (of different kinds) is expressed by several lexical items (adjectives, adverbs, verbs) at the same time:

hranila ju je mnogim ukusnim jelima

(fed her with many delicious dishes)

morala je mesti, prati posude, ici po vodu, cijepati drva...

(she had to sweep the floor, wash the dishes, go get some water, cut wood...)

the youngest group still recurs to the one adverb per child, the same one they prefer in predicates with only one intensifying adverb (very or well) $>$ dobro ju je hranila (she fed her well).

In the group of 7 and 8-years-olds only one child gives the syntagm, somewhat simplified: > davala finu hranu (used to give her good food), where the verb hraniti (to feed) is replaced by the nominal syntagm davati hranu (to give food).

The same as in the previous group, of the 9-years-olds only one child gives the expression, but turns back to the verb hraniti (to feed) > hranila finim jelima (fed her with delicious dishes). 
The same as in predicates containing only one intensifying adverb, the 12 years old boy summarises the meaning of several verbs: > stalno ju je njego vala (took good care of her all the time); rijetko ga je njegovala (rarely used to take care of him); morala je mesti, prati posude, ici po vodu, cijepati drva... (she had to sweep the floor, wash the dishes, go get some water, cut $\operatorname{wood} . ..)>$ nikad joj nije pomagala (she never helped her).

- When the source text contains an intensifying phrase, such as: mogla ih je moliti do mile volje (she could have begged as long as she wanted).

In the youngest group one child managed to repeat the phrase exactly, the other two omitted it entirely.

The 7-8-years-olds use neutralised expressions (if any), such as: nisu se odazivali (they did not answer); nisu se htjeli vratiti (they did not want to come back).

At the age of 9 years children are already able to paraphrase, or to use other similar phrases with approximately the same temporal value: mogla je moliti do jutra (she could have begged until the next morning); vise nikad nisu sisli (they never came back down); mogla je govoriti sto puta (she could have said hundred times); ma koliko ih je zvala, oni nisu htjeli doci dolje (as much as she called, they did not want to come down); some express the intensity by verb iteration: zvala je i dozivala (she called(imperfective) and called(prefixed imperfectivised perfective), cf. 2).

The 12 years old boy omitted the phrase.

It is to be observed that with age children use notably more intensifiers and more varied syntactic structures.

\subsubsection{Iterative}

The most interesting thing to be observed in iteratives is that they are almost exclusively used by the youngest group. The most used syntactic construction is adverb + verb (adverbs: cesto (often), nekad (sometimes), or simply a verb of iterative semantic (davati (to giveIMPF), pustati (to letIMPF)).

So the 6 years old children (all three of them) expressed some kind of iteration, notwithstanding the sometimes misplaced semantic (nije cesto isao spavati (he did not often go to sleep), samo joj je davala (she used to give her just...), samo joj je govorila (she just kept telling her...).

Of the five children from the group of 7 and 8 years olds, only two express an iteration: nekad joj nije dala jesti (sometimes she did not give her to eat), nisu se odazivali (they did not answer).

Only one child of the five in the 9 years old group used an iterative expression (for the abovementioned phrase: mogla je govoriti sto puta (she could have said that hundred times).

For the eldest boy (12) the iterativity is contained in the verbs only: davala joj je hrane (she used to give her food); davala mu ostatke (she used to give him rests of the food).

\subsubsection{Inchoative}

The same as in the source text, inchoatives appear in the children's narrations mostly in form of verbs denoting some kind of motion, although in the source text there is a greater variety of motions: 
podji (imperative: come (start moving) towards the speaker)

dodji (imperative: come (end moving) towards the speaker)

sisli su (perfect: they came down)

In the two youngest groups only two verbs express those motions: otisli su (they went away no matter the position of the speaker or the direction of the movement).

The same verbs appear in the two older groups, along with some other: povedi nas gore (take us up).

Although there are no phase verbs indicating the inchoativity in the source text, the two older groups ( 9 years + the 12 years boy) seem to be very prone to them: poceli su lupati (they started beating), poceli su se tuziti (they started lamenting), pocela je vikati (she started shouting) etc. Only one child from the younger groups (6 years) used one phase verb to express inchoativity: postala je nestrpljiva (she became impatient).

\subsection{Results obtained from French children}

\subsubsection{Aspect}

As already mentioned in the description for the Croatian source text, the French ST can be divided into two parts. In the 4 first sequences, all the verbs express an imperfective aspect (with imperfect tense and infinitive mood respectively). From the $5^{\text {th }}$ sequence on, the perfective aspect appears with 22 verbal occurrences in the Past Historic (passé-simple). However, other verbs express the imperfective aspect in this second part of the story as well. These are verbs with the tenses: imperfect, pluperfect, present, future, perfect, and the moods: infinitive, imperative, present participle.

In the youngest group (5-6-years-old) one child started to use the perfective aspect from the $4^{\text {th }}$ sequence on, and so did 2 children in the oldest group (10-11-years-old). These verbal occurrences in the perfective aspect (Past Historic) are wrong because it is impossible to mix certain tenses or certain aspects in the same sentence when the verbs appear in clusters. However, this new aspect corresponds, for the first time in the story, to the actions or duties that the frog has to perform. Consequently, one can argue that perfective aspect is related to the lexical meaning of the verbs. In the second part of all retellings (that is when children have to 'choose' between perfective and imperfective aspect), from the first occurring of the perfective aspect on, the results are quite different in respect to the age of the children.

We have divided all verbs of the ST and corresponding verbs of the retellings into perfective aspect (verbs in Past Historic) and imperfective aspect (all other verbs).

Table 1. The use of Perfective and Imperfective verbs in children's narratives

\begin{tabular}{llll}
\hline $\begin{array}{l}\text { Age } \\
(\mathrm{n}=6)\end{array}$ & $\begin{array}{l}\text { Perf. Verbs (total) } \\
132(100 \%)\end{array}$ & $\begin{array}{l}\text { Imperf. Verbs (total) } \\
432(100 \%)\end{array}$ & Errors \\
\hline $5-6$ & $59(44,7 \%)$ & $202(46,7 \%)$ & $2,6 \%$ \\
$7-8$ & $36(27,2 \%)$ & $217(50,2 \%)$ & $1 \%$ \\
$10-11$ & $45(34 \%)$ & $267(61,8 \%)$ & $5 \%$ \\
\hline
\end{tabular}


Table 1. shows how the aspects and the rates of errors are divided up in respect to the age ${ }^{1}$. In the group of 5-6 years of age, the rates of perfective and imperfective verbs are very similar in respect to the ST. This result shows that at the age of 5-6-years-old children adhere very closely to the forms they have heard, e.g., they tend to repeat the verbal aspect whatever it is.

In both older groups of children, the retelling differs in relation to the aspect in the ST. In the 7-8-years-old group of children less than $1 / 3$ of the perfective source verbs are retold; and in 10-11-years-old group of children $1 / 3$ of the perfective verbs are used in retelling. The low rate of errors ${ }^{2}$ in $7-8$-years-old children can be explained by the fact that they produce the least perfective verbs out of the 3 groups.

We argue that children, even in the youngest group, understand the differential value between perfective and imperfective aspect because the occurred verbs in perfective aspect are very different in the 3 groups of age.

From all the perfective verbs produced by each age group during retelling, we have extracted those perfective verbs which do not occur in the ST, nor in the speech of the children with the imperfective aspect. This allowed us to isolate the perfective verbs that children used on their own initiative.

The 5-6-years-old children produced 8 different verbs in perfective aspect : laver (to wash), porter (to carry), gronder (to scold), se fâcher (to get angry), demander (to ask), *fronder, répondre (to answer), appeler (to call).

The 7-8-years-old children produced 5 other types of verbs in perfective aspect : rester (to stay), partir (to go away), répliquer (to reply), avoir pitié (to pity), emporter (to take).

The 10-11-years-old children produced 7 different types of verbs in perfective aspect : s'endormir (to fall asleep), commencer (to begin), supplier (to beseech), emmener (to take), tourner (to turn), rentrer (to go back), s'acharner (to try desperately).

It can be noticed that 5 types out of 8 in the group of 5-6-years- old, refer to speech verbs (against $1 / 5$ in $7-8$ olds and 1/7 in 10-11 olds). Only in the group of 10-11-year-olds, the new verbs express inchoative (to fall asleep, to begin) or intensive (to beseech, to try desperately) Aktionsart. Unlike the perfective verbs, the imperfective verbs are almost the same in the 3 groups. These verbs are very frequent in the target language and very simple from a semantic point of view : 2 verbs of perception (regarder : to look at; voir : to see), 3 verbs of motion (aller : to go, descendre : to go down, monter : to go up), 2 verbs of speech (demander : to ask, dire : to say, to tell). A few other verbs, like s'asseoir (to sit down), attendre (to wait for), creuser (to dig a hole in) are directly related to the specificity of the story.

In spite of the fact that the Past Historic, which expresses (among other values) the perfective aspect in French, is unusual to encounter in tales, children use it with particular lexical verbs. Even if the morphological forms of verbs in Past Historic are wrong, children seem to 'choose' the perfective aspect that in French language is a very particular one: It expresses specific categories of meanings which correspond to the competence children have at a given age.

Perfective aspect can be seen as a marker for verb categories which are acquired on lexical and semantic levels: various speech verbs in 5-6-years-old group and complex verbs in 10-11years-old group, are verbs with a lexicalised Aktionsart.

1 The age groups have 6 children each. To make a comparison possible between each group of children and the ST, the number of occurrences in the ST are multiplied by 6.

2 Only the tense errors are relevant and counted and not the very frequent morphological errors which occur with Past Historic in children. 


\subsubsection{Aktionsart}

\subsubsection{Intensive Aktionsart}

- When intensive Aktionsart is expressed in the source text only with lexical words:

$\begin{array}{ll}\text { elle la dorlotait } & \text { (she spoiled her) } \\ \text { ils se lamentaient } & \text { (they cried their woes out loud) } \\ \text { pleurant sur leur misère } & \text { (crying a little - on their woes) } \\ \text { ils gémirent tant et tant } & \text { (they sighed so heavily) } \\ \text { impatientée } & \text { (impatient) } \\ \text { en colère } & \text { (angry) }\end{array}$

Children at the age of 5 to 6-years-old do not express intensive meaning because they do not use these words.

Children between the ages of 7 to 8 -years-old express intensive meaning in four distinct ways:

1) repeating the same verb (dorlotait - spoiled);

2) by using another verb or another adjective which expresses an intensive value (se lamentaient $>$ suppliaient $:$ begged $^{3}$; gémirent tant et tant $>$ après avoir tant prié : after they have so much pressed ; impatientée > inquiète : anxious);

3) by intensification (en colère > tout en colère : very angry); and

4) by a definitional reformulation (impatientée > elle en avait assez/marre : she had enough/she was fed up).

Children at the ages of 10 to 11-years-old express intensive meaning in the same way as the previous group, but they add more advanced ways to use intensifiers. They use semantic paraphrase (ple urant sur leur misère > ils s'apitoyent sur leur sort : they feel sorry for oneself); transformation of the quantitative intensity into durative intensity (tant et tant > pendant un bon bout de temps : during a very long time); or they change the grammatical category (Adj. impatientée > V. s'impatiente).

- When the intensive Aktionsart concerns several notions: quantity, diversity and quality, these notions are transformed into iterative or durative by the youngest children:

5-6-years-old

elle lui donnait toutes sortes de bonnes choses à manger > elle lui donnait à manger

tous les soirs

(she gave her all sorts of good things to eat) > (she gave her to eat every evenings)

Diversity and negative quality: elle le laissait dehors par tous les temps (she left him outside in all weathers) $>$ Durative (...) tout le temps (all the time).

7-8-years-old children expressed 2 different notions: quantity and quality, but with other grammatical categories:

elle lui donnait toutes sortes de bonnes choses (dét $\mathrm{N}$ prép Adj $\mathrm{N}$ ) à manger > elle était bien nourrie ( $\mathrm{Adv} \mathrm{V}) /$ elle lui donnait bien à manger $(\mathrm{Adv} \mathrm{V})$

(she gave her all sorts of good things to eat)

Se lamentaient $>$ suppliaient is to understand as : sequence of the source text $(\mathrm{ST})>$ retelling of this latter sequence by a given child 
Or they explain the intensive phrase (par tous les temps: in all weathers):

elle le laissait dehors même au mauvais temps

(she left him outside even in bad weather)

Children in the 10 to 11-years-old group, expressed the 3 different notions (quantity, diversity and quality) together in a paraphrase:

elle lui donnait toutes sortes de bonnes choses à manger > elle lui offrait plein de

choses de bien à manger

(she gave/bought her a lot of good things to eat)

- When the intensive Aktionsart is expressed with an aspectual or modal operator, 5-6-yearsold children express intensive with other categories:

Elle eut beau (operator: intensive and iterative) les supplier (she begged in vain) $>* l e$ chien tellement (intensive/quantitative Adverb) qu'elle supplia le chien et la lune redescendait pas

Elle l'obligeait à (modal verb) travailler (she made her work) > elle devait faire_tout le travail / plein de travail (the intensive obligation of 'obligeait à' becomes a big quantity of work with the determiner plein de)

Children between 7 to 8-years of age, express the intensive and iterative Aktionsart with an agrammatical sentence:

Elle eut beau les supplier > *elle a beau tant crier

10-11-years-old children, express the complex Aktionsart of the source sentence only with a durative Aktionsart:

a. Elle eut beau les supplier > malgré qu'elle ait crié pendant longtemps

(during a long time)

Or only with an iterative meaning:

b. Elle eut beau les supplier > la grand-mère cria plusieurs fois

(several times)

Or the complex Aktionsart (intensive \& iterative) is expressed in a paraphrase (more or less):

c. Elle eut beau les supplier > ? elle s'acharna sur son sort

(she tried desperately)

Just as younger children, older ones express the complex Aktionsart of the modal verb with a noun phrase, but in the oldest group of children the noun phrase refers both to quantity and diversity:

d. Elle l'obligeait à travailler > elle donnait plein de corvées à la grenouille

(she gave a lot of chores to the frog).

- When intensive is expressed with $V A d v A d j$ (elle était très heureuse: she was very happy), all children retell the same categories but in the youngest group the intensive use decreases, or a negative replaces a gradual comparison: le chien était moins heureux (the dog was less happy) > le chien était pas heureux (was not happy). 
7-8-years-old children express both, intensive and gradual comparison.

10-11-years-old children may replace the source verb with another verb, and the quantity notion is expressed with a quality notion. The reformulation maintains the intensive Aktionsart:

Elle l'habillait bien chaudement > elle lui offrait de beaux habits.

\subsubsection{Iterative Aktionsart}

The iterative Aktionsart is expressed in the source text with: 1) verbal lexicon: coasser (to croake), aboyer (to barke), nourrir (to feed), soigner (to take care); 2) with a plural noun phrase: toutes sortes de bonnes choses (all sorts of good things); 3) with an adverb: souvent (often); 4) with the combination verb - adverb: gronder tout le jour (to scolde all day); 4) with a repetition of the same verb: elle regarde à droite elle regarde à gauche (she looked to the right and she looked to the left), elle cria elle cria (she called and she called).

As mentioned elsewhere in the text, some sentences express a complex Aktionsart, that is both iterative and intensive (dorloter - to spoil; gémir tant et tant - to sigh so heavily and so often; avoir beau supplier - to beg in vain; toutes sortes de bonnes choses - all sorts of good things).

We now examine only the use of iterative Aktionsart in new cases.

\section{Iterative in verbal lexicon}

None of the children in the 5 to 6-years-old group repeated the verbs: coasser (to croake) and aboyer (to bark), but produced speech verbs such as dire (to say), répondre (to answer), and the general verb : faire (to do). Few older children repeated these two verbs; the others used speech verbs like younger children.

The verbs nourrir (to feed) et soigner (to take care) were used by all children (as direct speech). One child in the second group (7-8-years-old) gives a definitional reformulation of $j e$ vous ai nourris (I fed you) with je vous ai donné à manger (I gave you to eat).

\section{Iterative in adverb}

a. La vieille ne le caressait pas souvent (the old woman didn't pet him very often) (ST)

b. Souvent elle allait se coucher sans avoir dîner (she often went to bed without any supper) (ST)

No differences were observed in the use of iterative adverb in all 3 age groups. The adverb occurs generally in sentence (a). In sentence (b) the same adverb doesn't occur and is changed in des fois (sometimes) in only 2 children, probably because of the first place of the adverb ${ }^{4}$

Iterative in combination verb - adverb: no occurrence at all in children

Elle avait grondé la petite grenouille tout le jour

(she had scolded the poor frog all day) (ST)

\section{Iterative in repetition}

a. Elle regarde à droite elle regarde à gauche

(she looked to the right and she looked to the left) (ST)

$4 \quad$ When the adverb or any other complement occurs in the first place it is usually not constructed by the verb of the sentence. Till at least 7 years, $90 \%$ of the sentences have only arguments, that is complements which are constructed by the verb (Martinot, 2003). 
b. Elle cria elle cria

(she called and she called) (ST)

The repetition of the verbs occurs the more in older children. At 7-8 years children confirm the aspectual iterative with un coup:

Elle regarde un coup à gauche un coup à droite

(she looks once to the right once to the left)

To notice: When the Aktionsart is complex, the iterative meaning is generally omitted except in oldest children.

\subsubsection{Inchoative Aktionsart}

The inchoative is only realised in the source text in 2 sentences. First with the support verb in:

a. Elle les prit en pitié

(she took pity on them);

and with the meaning of the verb in:

b. Vous m'abandonnez

(you have run away from me)

The youngest children do not express at all (a), the older (7 to 8 and 10 to 11) express another support verb, avoir, with a durative meaning:

Elle a eu pitié d'eux

(she had pity on them)

The sentence (b) is repeated by all children, if not the new verb expresses an inchoative Aktionsart:

5-6: $\quad$ vous me quittez (you leave me)

10-11: vous partez (you go away).

\section{$5 \quad$ Provisional conclusions}

The reformulation paradigm allows the researchers to follow the linguistic growth in children at different stages of language acquisition. Moreover, the idea of a specific controlled text that can be translated into different languages and used with different ages of children, provides an ideal background for crosslinguistic studies.

Our data indicate some differences in the use of aspect between French and Croatian speaking children. In French children the occurred verbs in the perfective aspect are very different in the 3 groups of age unlike verbs in the imperfective aspect which are very similar in all French speaking children. In Croatian language children always keep the appropriate aspect unlike in French children, even in the eldest group, which replace often imperfective (in the ST) with perfective aspect and vice versa.

However, in both languages, one can notice the sudden switching from imperfectives to perfectives even if errors occur in French children in the second part of the story. Thus, one can argue that perfective aspect, the marked form in both languages, is related to the lexical meaning of the verbs, whatever the language. 
Then our data indicate specific developmental trend in the use of Aktionsart by children speaking Slavic and Romanic languages. In both languages (Croatian and French) the highest diversity of means was found in the expression of intensive Aktionsart.

The youngest children in both linguistic groups prefer an intensive adverb rather than an intensive verb. They often omit the verb when they do not know its meaning.

By the age of 7-8-years-old, children produce exact synonyms, or definitional reformulations. The growing linguistic abilities allow them to replace the source sentence structure and express more than one Aktionsart in a verb (intensive \& iterative).

The oldest children can express 3 Aktionsarten in a verb, producing complex verb structures. They are also capable to produce many different paraphrases of a source text without losing its meaning.

The iterative Aktionsart is almost exclusively used by 5-6-years-old Croatian children: there is less frequency of iterative Aktionsart use in narratives of the older groups of Croatian children. In French language, the iterative is used by the youngest children in the form of direct speech, but not in the indirect one.

From the age of 9-years-old on, the inchoative Aktionsart is expressed by children in both linguistic groups by phase verb, aspectual operator, or support verb.

In conclusion, our data indicates that, in spite of the differences between the two languages regarding the morphological possibility of expressing it, there are more similarities than differences in the use of Aktionsart by French- and Croatian-speaking children. This might indicate that the acquisition of the Aktionsart is more a matter of semantics than of morphology, which shows the practical value of comparisons like this one.

\section{References}

Andel, M., Klampfer, S., Kilani-Schoch, M., Dressler, W. U., Kovacevic, M. (2002): Acquisition of verbs in Croatian, French and Austrian German - an outline of comparative analysis. Suvremena lingvistika 49-50, 525.

Andel, M., Kuvac, J., Vancas, M. (2003): L'acquisition par reformulation en croate. La reformulation: un principe universel d'acquisition (Claire Martinot \& Amr Ibrahim, eds.). Paris: Kimé.

Bariæ, E., Lonèariæ, M., Maliæ, D., Pavešiæ, S., Peti, M., Zeèeviæ, V., Znika, M. (1995): Hrvatska gramatika (Croatian Grammar). Zagreb: Školska knjiga.

Comrie, B. (1976): Aspect. An introduction to the study of verbal aspect and related problems. Cambridge: Cambridge University Press.

Frawley, W. (1992): Linguistic Semantics, Hillsdale, New Jersey.

Gross, G. (1996): Prédicats nominaux et compatibilité aspectuelle. Langages 121. Paris: Larousse.

MacWhinney, B. (1995): The CHILDES Project, Tools for Analyzing Talk. Lawrence Erlbaum Associates. Hillsdale, New Jersey.

Martinot, C. (2000): Etude comparative des processus de reformulations chez des enfants de 5 à 11 ans. Langages 140. Paris: Larousse.

Martinot, C. (2003) : Comment parlent les enfants de 6 ans? Pour une linguistique de l'acquisition. Besançon : Presses Universitaires de Franche-Comté (PUFC).

Martinot, C. \& Ibrahim, Amr (Eds.) (2003): La reformulation : un principe universel d'acquisition. Paris: Kimé.

Ridjanovic, M. (1976): A synchronic study of verbal aspect in English and Serbo-Croatian. Cambridge, MA: Slavica Publishers Inc.

Sokolov, J. \& Snow, C. (Eds.) (1994): Handbook of research in language development using CHILDES. Hillsdale, NJ: Lawrence Erlbaum Associates. 